\title{
1. Rethinking third places and community building
}

\section{Caryl Bosman and Joanne Dolley}

\section{INTRODUCTION}

Ideals of community as produced by many planning discourses - in Australia, the UK and America - in the 2000s are not dissimilar to their historical forbears. Most remain associated with aspirations to "the good life', a more caring, sharing, connected and united world (Freie 1998). An imagined gemeinschaft village life is still a popular image of 'community': small scaled, place-based, face-to-face relationships, self-contained, self-governing and self-referential. However, the unquestioned belief that physical planning can create ideals of community and provide the necessary ingredients for 'the good life' is no longer axiomatic. The often simplistic interpretation of 'community' has meant social and cultural difference has not always been recognised and everyday life patterns have been largely regulated by the 'master' plan. We argue that the values attributed to ideals of community have been re-invented, re-produced and re-inscribed, over the course of the twentieth century as universal and unquestionable 'truths'. This chapter maps some of the planning techniques and rationalities that underpin these 'truths'; 'truths' that ultimately affect the planning and development practices that comprise many contemporary city landscapes and in particular in the case of this book, third places.

This first chapter introduces the concept of third place and establishes a critical platform for understanding the relations between place and community. The chapter concludes with an outline of the book structure. The chapters in this book highlight the importance of third places and how they can be incorporated into urban design to offer places of interaction - promoting togetherness in an urbanised world of mobility and rapid change; frequently cited causes for the demise of community and the decline in social health and well-being. The book chapters analyze a diverse array of spaces identified as third places, authored by scholars from different disciplines and from different countries around the world. 


\section{RETHINKING THIRD PLACE}

In 1989 the sociologist, Professor Ray Oldenburg, released the influential book The Great Good Place: Cafes, Coffee Shops, Community Centers, Beauty Parlors, General Stores, Bars, Hangouts, and How They Get You Through the Day, in which he described his concept of third place. Third place is a concept which identifies places which are not home (first place) or work (second place), but are 'informal public gathering places' (Oldenburg 1997 p.6). They are neutral places which provide opportunities for people to meet and interact and to develop a sense of belonging to place (Oldenburg 1999). Oldenburg (1989) attributes eight distinguishing characteristics in defining or identifying third places:

1. Neutral ground or a common meeting place.

2. Levellers or places that encourage, and are inclusive of, social and cultural diversity.

3. Places that are easy to access and accommodate various sedentary and active activities.

4. Place champions or regular patrons.

5. Low profile and informal places.

6. Places which foster a playful atmosphere.

7. A home away from home.

8. A place where conversation is the primary activity.

Third places are as relevant at the end of the second decade of the twentyfirst century as they were 30 years ago. Urbanisation and its associated problems and solutions, and in particular the effect on community relations, remain 'hot topics'. Loss of community and sense of place is often identified as a problem by social researchers. Oldenburg (1997 p. 7) wrote: 'Life without community has produced, for many, a life style consisting mainly of a home-to-work-and-back-again shuttle. Social well-being and psychological health depend upon community'. One conceptual place where community building occurs is the third place. In a time of rapid urbanisation, with a UN projection that 75 per cent of the population will be living in cities by 2050, there is a critical need to revisit third place as a possible contribution to easing increasing levels of anxiety and loneliness and thereby contributing to the health and well-being of individuals and communities (Hollis 2013; Jacobs 1996; Firth et al. 2011; Putnam 2000).

There has been a great deal of interest in the concept of third place. A 2018 Google Scholar search on Oldenburg's 1989 book found it cited in 2634 articles. Oldenburg published his second third place book Celebrating The Third Place: Inspiring Stories about the 'Great Good Places' at the 
Heart of Our Communities (2001) at the turn of the century. The book is a collection of 19 essays which tell stories by proprietors and patrons about successful businesses in the USA which have purposely incorporated third place in their physical planning and urban design schemes. These include a shopping centre, tavern, restaurant, coffeehouse, garden shop and a bookstore. Both of Oldenburg's books continue to inspire research across a broad range of locations and in a variety of theoretical frameworks. For example, authors have incorporated the third place concept into the design of aged care facilities; many have explored new types of third places such as libraries, parks and other non-commercial public places; and others have investigated cyberspace and social media in terms of third places. For example, Mele et al. (2015) found that wet markets in Singapore are a good example of third places, facilitating casual and regular social interactions between local residents across ethnicities, gender and socio-economic status. Jones et al. (2015) discovered that fast food outlets act as effective third places bringing together ethnically diverse customers, facilitated by their predictability and ubiquity. There are ever new places which can be added to the list of third places, including the camaraderie which is evident in smoking zones in the countries with limited public spaces for smoking; or the height of popularity of the game of Pokemon Go, where everyone from school children to adults with child-like wonder traipsed through churchyards, building foyers, parklands using their mobile devices searching for place-based electronic creatures.

Third places are important because they act as 'mediation between the individual and the larger society' and increase neighbourhood sense of belonging and community (Oldenburg 1999 p.xxix). Numerous social researchers suggest that everyday incidental interactions of third places improve relationships between neighbours; decrease loneliness and isolation; improve the perception of safety; build social capital and create a sense of place (Oldenburg 1999; Thompson and Maggin 2012; Galdini 2016; Vincent et al. 2016).

\section{PLANNING FOR COMMUNITY: HISTORICAL LEGITIMISATIONS}

This section highlights particular sites in which ideals of community were/ are employed as planning techniques, with the intention to produce specific outcomes and achieve particular economic ends - disciplined, docile subjects and collectives. We draw attention to Ebenezer Howard's Garden City; Frank Lloyd Wright, Raymond Unwin and Charles Reade's versions of the same; New Urbanist interventions and Eco-Village promulgations 
primarily to suggest some of the historical precedencies that many urban planning discourses re-produced as more-or-less 'truthful', 'normal' and 'good'. In addition, by including references to some of the 'heroic' patriarchal planning histories - Howard, Wright, Unwin and Reade - it is not our intention to re-inscribe, what Leonie Sandercock refers to as totalising modernist narratives. Rather, following Sandercock the revisiting of these histories is to 'recover, to make visible, these stories that have been rendered invisible' (Sandercock 1998 p. 5). It is pertinent to consider the planning context and historical ideals of community as the context for third places. As Oldenburg explained, 'American planners and developers have shown a great disdain for those earlier arrangements in which there was life beyond home and work' (Oldenburg 1989 p. 18). This leads to Oldenburg's description of third places as 'those gathering places where community is most alive and people are most themselves' (Oldenburg 1989 p. 40).

\section{Garden City Emergences}

One of the most enduring and influential planning treatises that sought to construct the site of 'community' as civil, moral and good was Ebenezer Howard's Garden City model. Howard (1850-1928) drew from a wide range of literature and ideas of the late nineteenth century to address issues arising from the mass migration of rural dwellers to city centres. Through planning and design of self-contained and self-governing Garden Cities, linked by rapid transport routes, Howard sought to provide the accessibility and sociability of the city together with the healthiness of country life. In his book To-morrow: A Peaceful Path to Real Reform the Garden City is given as being aligned with nature, offering social opportunities, ample recreation areas that are readily and easily accessible to all residents, a healthy inexpensive lifestyle, clean air and water, well paid employment opportunities, sound investment potential, and the freedom of individuality within the context of 'community' co-operation (Hall and Ward 1998). It was thus fully inclusive. Howard's aim, according to Jane Jacobs, 'was the creation of self-sufficient small towns, really very nice towns if you were docile and had no plans of your own and did not mind spending your life among others with no plans of their own' (Jacobs 1972 p. 27). The Garden City is given as the epitome of 'the good life'; an ideal rather than a lived experience. In this model all residents are disciplined, docile and obedient subjects and there is no dirt, poverty, illness, or disease. Notwithstanding, Howard did acknowledge the existence of individuals who required specialised care. He notionally allowed for a lunatic asylum sited within the greenbelt bounding the Garden City. 
Howard's Garden City 'community' included a range of people from industrial capitalists to low paid labourers and the political structure of the Garden City was based upon equality, mutual consensus, sharing and fairness. The boundaries of the Garden City are restricted and fixed by the feasibility of all members to participate in a mutual communicative process, so limiting the number of people who can live within the city. Also, membership of the collective is only ascribed to those who actively and physically participate. Those who choose not to participate or are unable to, are alienated or deemed to be deviant. The Garden City model, thus delineates the included 'us' from the excluded 'them' and determines what is 'ours' and what is 'theirs'.

At the same time that Howard was experimenting with his Garden City model, the American architect Frank Lloyd Wright (1867-1959) was arguing for a city planning approach that reflected and embodied democracy and the modern world. Wright's utopian vision for 'Broadacre City', as with Howard's Garden City, emerged at a time of social dis-ease, with the 'ills' of capitalism and overcrowding being the primary impetus for city planning practices of the day. Wright's planned city, as with some of his contemporaries - in particular the Swiss/French architect, Le Corbusier was largely premised on the belief that physical planning practices could produce the greatest happiness for the greatest number. Thomas Osborne and Nikolas Rose (1999 p. 747) argue that Wright's model city - as with Corbusier's versions - was a governmental space: 'in the sense that the construction of this organic social city and the normal citizen who will inhabit it functions as the regulative ideal of a range of programmes and initiatives within which the normal citizen is the social citizen of what [has been called] "healthy social communities"".

As did Howard, Wright too sought to create an urban environment that would facilitate healthy and happy subjects, achieved through planning techniques that deployed ideals of community. Wright's Broadacre City, as the title implies, was a merging of city life and country values. Wright sought to establish 'community' through the provision of extensive farm and recreational areas, pollution free factories, local schools, a range of houses to cater for a cross-section of the population, and an inclusive local government structure. Wright argued for an organic architecture that responded to local topographies, climates, and functions. Like Howard, Wright recognised the importance of modern technology rather than harking back to the Middle Ages for his imagery, as some of his English contemporaries - Raymond Unwin in particular - were advocating. Wright's model city boldly embraced modern ideology, the car and manufactured standardised components. By the 1960s, however, these Modernist town planning techniques and practices were being criticised 
for producing a 'low grade, uniform environment from which escape was impossible' (Mumford 1991 p. 553). This criticism was reiterated in the 1990s by the New Urbanists - as argued below - who blamed Modernist planning practices for the demise of 'community' and all that pertains to 'the good life'. Oldenburg (1989 p. 180) describes the effects as: 'The planners and developers continue to add to the rows of regimented loneliness in neighborhoods so sterile as to cry out for something as modest as a central mail drop or a little coffee counter at which those in the area might discover one another.'

In Britain, Modernist town planning techniques and practices were mostly portrayed in the post World War Two re-workings of Howard's Garden City model, renamed 'New Town'. The early New Towns were government incentives with a focus on public housing and employment opportunities, although not always within walking distance as with Howard's model. This new version of the Garden City sought to address issues arising from the post war period: affordable housing for returning war veterans, the growing use of the motor vehicle, and the fashionable shopping mall. Oldenburg (1989 p. 282) noted the post World War Two period as a turning point for an 'informal public life' as people retreated to their homes and corner stores and cafés have 'fallen to urban renewal', replaced by freeways and modern infrastructure.

Although New Town planning techniques were influenced by and reflected contemporary (late 1940s-1950s) trends and technologies, at the same time they largely drew upon and re-produced Howard's early 1900s city-in-the-country model. New Towns were sited in rural areas and as such were promoted for their country lifestyle; a 'more balanced and complete community life' (Freestone 1989 p. 227). Many New Town planners looked to a past romanticised ideal of village life to create an essentially urban 'community'. In these instances ideals of community were invoked to depict nostalgia for the 'good old days'. The historically imagined, gemeinschaft ideals of community that the planners were promoting, however, seemed no longer applicable or possible. The changes in lifestyles and trends in the late 1950s and 1960s suggested many people did not have the same connection to place that traditional village life relied upon. Increased mobility during this time, higher wage opportunities, and changes in gender roles and technology - and therefore labour requirements - often meant fundamental changes to many urban living patterns. Oldenburg (1989 p. 285) noted, 'Segregation, isolation, compartmentalization and sterilization seem to be the guiding principles of urban growth and renewal.'

As with Howard and Wright's city planning models, New Town ideals of community were to be achieved primarily through the provision for 
a range of houses to cater for a range of people. Unlike some of the nineteenth-century social mix planning techniques - that co-located working and middle class housing - the planning of New Towns relied on the social and physical segregation and ranking of blue and white collar workers. B.J. Heraud (1968 p. 35) argues that there was a supposition held by many New Town planners that, exposure to a 'mixed environment' would 'enlarge people's horizons and so benefit society as a whole'. In addition, Mark Peel (1992 p. 25) suggests that there was a general belief among many planners, at the time, that New Towns 'if planned properly, could still produce valued social outcomes-social mix, neighbourhood community, and village-like social relationships'. This achievement was flawed from the outset given the differences between the spontaneous and irregular characteristics of village layouts and the planned and controlled New Town landscapes. As N. Dennis (1968) points out, village life revolved around an overlapping and complex web of everyday relationships with people who were generally known and named. New Town planning, however, involved a group of new residents who did not necessarily know each other or have anything in common. It could be argued that this set of circumstances cries out for informal meeting places. Oldenburg (1989 p. 286) discusses the challenges of 'trying to enjoy life amid a badly designed environment' and suggests that 'grass roots efforts are the best hope for creating enjoyable urban habitats'. Several chapters in this book discuss grass roots efforts to create a sense of community, in particular, Chapter 7 which looks at music archives and Chapter 8 on community gardens.

By the 1980s, the commitment of the Australian government (and the British government) to New Town programmes was dwindling. This was partly the result of increased migration, demographic and lifestyle shifts and changes in modes of government. The withdrawal of the government from direct involvement in the planning and development of new residential areas opened opportunities for private enterprise intervention.

\section{Village Idyll}

Although Howard did not fully realise his Garden City dream, his work was the impetus for others who believed they could instigate social reform through planning for ideals of community. Raymond Unwin (1863-1940), having resigned as Howard's Garden City architect, remoulded Howard's model in line with his own ideology. Unwin focused more on middle class residential commuter suburbs. He drew heavily on the Arts and Crafts Movement of John Ruskin and William Morris and turned to the Middle Ages for his imagery and ideals. This bias was encapsulated in his book 
Town Planning in Practice first published in 1909. In effect, through specific town planning practices Unwin sought to regulate everyday life of the individual, in accordance with particular ideals of community, an argument which is taken up a little later.

For Unwin, village life encapsulated 'the good life' and ideals of community. The village was a site of both social and aesthetic value; social in terms of bringing together a group of like-minded people, with similar values and interests, and aesthetic in the sense of place creation. Unwin believed that through the use of local building materials and practices, residents would establish an identity and a sense of belonging to place. This common identity he argued established 'community', as people shared common ties and memories. Unwin's concept of 'community' is thus closely aligned with gemeinschaft relationships. Here, 'community' is consigned to being rural as opposed to urban. It is associated with belonging rather than alienation, communality rather than individualism and the traditional rather than the modern. The urban versus rural dialectic is played out in a direct and blatant fashion. Howard sought to sift the qualities associated with 'the good life' from both poles in his Garden City model, while Unwin drew almost exclusively from the rural pole. In Unwin's argument for a 'new form of community that would rise up out of the land, clear, clean, honest and alive' (Unwin 1994 p. xxi), place-based relationships and imagined, 'golden age' values are re-inscribed.

Unwin sought to rationalise, re-organise and rank the largely incremental and spontaneous planning practices that informed village life in pre-industrial England. He stated that (Unwin 1901 p. 93):

It is the crystallisation of the elements of the village in accordance with a definitely organised life of mutual relations, respect or service, which gives the appearance of being an organised whole, the home of a community, to what would otherwise be a mere conglomeration of buildings.

This attempt by Unwin, to create a 'new form of community' by developing low density residential 'villages' for like-minded people, has been criticised for propagating suburban sprawl and reinforcing social polarisation. As we will demonstrate, many current planners and developers also promulgated village planning techniques and practices as a means to produce ideals of community.

Unwin's village model emerged in the antipodes and found its way to South Australia through Charles Reade (1880-1933). Reade was commissioned by the South Australian government to design a garden suburb as a model example of latest planning practice. The new fully planned village, now known as Colonel Light Gardens, contrasted with existing suburban development which was largely haphazard and subject to opportunists 
and laissez-faire practices. Australian suburban development had emerged in opposition to the slums; the 'dense, dirty, unnatural, disorderly and disease ridden, vs [the] open, clean, natural and healthy' (Davison 1993 p.3). Reade traded heavily on this imagery in his argument for the village model. Reade's model was underpinned by and realised through the implementation of planning techniques pertaining to ideals of community.

Like Howard and Unwin, Reade attempted to plan a residential setting that would be manifest through largely utopian images of docile and happy 'community' subjects. Reade's village model represented a healthy environment, an enclave for white nuclear families, a moral and upright 'community', stability, conformity and a sound financial investment (Freestone 1989 pp. 84-85). The Australian suburbs have historically been socially exclusive places, home only for those who could afford to move from the dense and overcrowded cities to embrace the country lifestyle which suburbia promised.

\section{Urban Villages $^{1}$}

Much of the recent (1990s-2000s) planning rhetoric about the re-creation of villages and re-establishing of 'communities' is essentially about a lifestyle that is walkable. In these discourses a walkable lifestyle is promoted as being one that fulfils and sustains everyday needs within the locality, so reducing the need to use non-renewable resources. In these new villages, the government of everyday life is through practices of social interaction, through physical mobility (walking or cycling) and local travel. The Modernist planning techniques regulated behaviour through motorised travel and many Modernist planners argued that this mode of travel liberated the individual. Liberation and 'freedom' are now construed in relation to physical mobility. Through planning practices that emphasise pedestrian propinquity, individuals are 'liberated' from the car and from the negative impacts of suburban landscapes. Howard's Garden City model too, allegedly, offered residents 'freedom' to walk to places of employment and places of recreation. This focus is reiterated in the New Urbanists discourses: passive social contact, proximity and appropriateness of space.

The New Urbanist Movement was established in the early 1990s by a group of American architects and its proponents believe it 'is poised to become the dominant real estate and planning trend of ... [this] century' (Steuteville 2000). The New Urbanist Movement (largely operated

1 The term 'urban village' was popularised by HRH The Prince of Wales in the 1980s. 
through private enterprise practices) has had a significant impact on some of the planning policies, legislation and projects set up by the American Federal Department of Housing and Urban Development (HUD). The movement is described as a reworking of traditional neighbourhood ideology for the social environment of the 1990s (Fulton 1996). Heidi Landecker (1996) likens the movement to a new religion with prophets (founders Peter Calthorpe, Elizabeth Plater-Zyberk and Andres Duany), a Bible (The New Urbanism: Toward an Architecture of Community ed. Peter Katz) and thirteen commandments given to regulate planning and development practices. New Urbanist development practices have been primarily taken from Unwin's Town Planning in Practice first published in 1909 and Clarence Perry's 'Neighbourhood Unit' of 1929.

New Urbanist discourses claim to address the 'ills' of Modernism and the 'evils' of conventional suburban planning of the 1930s and 1940s. Modernist architects, such as Le Corbusier and Frank Lloyd Wright, are blamed for the demise of 'vital communities' by privileging private over public spaces, focusing on the motor vehicle and instigating segregation policies (Calthorpe 1994 p.xv). The Modernists, Vincent Scully (1994) laments, killed the traditional city and everything that pertained to 'the good life': 'community', 'correctness' and 'humanness'. Many New Urbanists consider American suburbia to be a landscape that largely inhibits experiences of 'the good life' - ideals of community and gemeinschaft relationships. Suburbia is depicted as being lonely and isolated, without public spaces to gather informally; a place where children grow up unbalanced, without any understanding of traditional (gemeinschaft?) values, morals or social responsibilities (Audirac 1999). As Oldenburg (1989 p.282) described, 'Adolecents spend more time in shopping malls than they do in any place beyond home and school. The duel degree is in consumership and passivity'. In response to the view of suburbia, many New Urbanists argue for a return to a cherished national icon, 'that of a compact, close-knit community' (Katz 1994 p.ix) achieved through comprehensive, historically founded, more-or-less 'truthful' planning techniques.

As such, the New Urbanist ideology remains within a Modernist agenda. The Modernists too believed that by the design of physical infrastructure particular social patterns could be created or influenced. For them it was through the dominance of car travel and the development of tower blocks. The New Urbanists seek to achieve the same end through a return to traditional village life. Both argue for the creation of 'community' (however defined) achieved through planning and built form as the means to cure the contemporary 'ills' of society. While the Modernists sought to achieve their end through the celebration of new technology and affirming 
their belief in the future, the New Urbanists look to a romanticised past (a pre-capitalist, pre-industrial, pre-motorised era) for their realisation of 'community' (Audirac and Shermyen 1994).

For the New Urbanists, it is the fundamental qualities of small country towns or villages that they wish to emulate, rather than city urbanity. Peter Calthorpe gives the key New Urbanists planning determinates as being 'pedestrian scale, an identifiable centre and edge, integrated diversity of use and population and defined public space' (Calthorpe 1994 p. 122). These 'post-suburban' developments are proposed to include the urban advantages of employment, civic, commercial and retail opportunities coupled with the rural advantages of clean air, healthy lifestyles and open public spaces. These qualities the New Urbanists state - as did Howard - are essential for 'restoring functional, sustainable communities' (Steuteville 2000).

In keeping with Howard's Garden City model and the subsequent derivatives, the New Urbanists' claim for 'community' also includes a variety of house types and styles for a range of life stages and incomes. The New Urbanist Charter (Congress for the New Urbanism 1998) states 'Within neighborhoods, a broad range of housing types and price levels can bring people of diverse ages, races, and incomes into daily interaction, strengthening the personal and civic bonds essential to an authentic community.' The difference between the earlier city/town/village planning models and the New Urbanists models rest in private enterprise interests. Ideals of community become a commodity only for those who can afford them.

The rationalities of government underpinning these new 'fully planned communities' are no longer fuelled by aspirations of social reform for the poor. Rather, they are influenced by market forces, where ideals of community are commercialised and sold as a commodity for profit. Any remnant of social reform embedded in these rationalities applies only to those who can afford it. Andres Duany and Elizabeth Plater-Zyberk suggest that middle-class home owners reduce the number of cars per family, in order to set back the higher costs of living in a New Urbanist development. They state 'No other action of the designer can achieve an improvement in the availability of housing for the middle class comparable to the sensible organization of a good neighborhood plan' (Duany and Plater-Zyberk 1994 p. xix).

In arguing for a new (or not so new) pattern of urban development the New Urbanists assume that the majority of Americans are inherently unhappy and dissatisfied with suburban life: a large allotment, detached house, back yard, privacy and car reliance. Some research suggests however, that suburbia fosters positive relationship networks because 
residents tend to be of similar life stages; for example, young families, families with teenagers or retirees.

The use of ideals of community as planning techniques - be they espoused by New Urbanists or others - has ethical implications in that planners become implicated in regulating and moulding behaviour patterns to certain ends: collective cohesion, interaction, sharing, supportive networks, membership and personal investment. Ideals of community utilised as planning techniques also assumes that individuals have a predisposition for neighbourly interaction, irrespective of personal histories, incomes and beliefs. In addition, they assume that residents will be happy to reduce or moderate their use of the car in an environment that is not always conducive to the economic journey. Oldenburg (1989 p. 286) refers to informal public life of the past as the 'triumph of the space user over the space planner - we simply took over establishments and spaces created for other purposes. What is revolutionary about our new environment is its unprecedented resistance to user modification.'

\section{'Sustainable' Villages}

More recently a new village product has entered the housing market. This fully planned product, or Eco Village, is designed in accordance with accepted sustainability principles; most commonly: recycling, solar power and rain water retention infrastructures. Many Eco Village discourses re-inscribe New Urbanist planning techniques in a bid to create ideals of community. Hugh Barton (2000 p. 11) defines an Eco-Village as 'an attractive, convivial and healthy place that balances privacy with community and local provision with city access'. As do the New Urbanists, EcoVillage discourses also argue for ideals of community as produced through an assemblage of urban and rural lifestyle rhetorics. Similar to Unwin and Wright's theorisations, identity with place is to be achieved through practices of planning and architecture, which are to respond to the local climate, topography and landscape. The model for these contemporary villages suggests they are located in country areas and include a range of employment opportunities to cater for all skill levels. Eco-Village proponents also argue for residential diversity - a range of house sizes and styles and diversity of people, from across the full spectrum of the population - as a planning technique essential for the production of 'sustainable communities'. It is through the practices of planning and architecture that, Alison Gilchrist (2000 p. 150) suggests, ideals of community become 'inextricably linked to sustainability'.

Eco-Villages are also resource inclusive developments with a focus on pedestrian propinquity; in that schools, retail, commercial and civic 
amenities are provided for, in conjunction with residential accommodation. Like the New Urbanists, the assumption underpinning Eco-Village planning techniques is that the provision of local amenities and an emphasis on pedestrian propinquity will produce friendly verbal interaction and local networks will be established. Importantly, this 'sustainable' village model is based upon efficient networks of activities and travel within and between villages, so eliminating the need for a privately owned motor vehicle, and traditional village values apply: gemeinschaft relationships and 'the good life'.

Eco-Villages, as with previous schemes, have been criticised for ignoring the existing pattern of contemporary life. Taylor (2000 p. 28) suggests that a 'new' model of development is not what is required to achieve the desired and much debated ecologically sustainable - and we would add 'community' formation - goals. Rather, planners, architects and other urban theorists need to work within the given fabric of modern urban life if any significant change is to be realised. Goals need to be realistic rather than based on utopian ideals of social mix and ideals of community. Peter Hall and Colin Ward (1998 p. 121) suggest this involves, among other things, equally top-down State regulations and bottom-up local approaches. In our positioning of third place, this book acknowledges both these governmental modes of producing place and community networks. This historical background provides the rationale for the variety of planning and design contexts within which third places exist (or don't exist) and in which grass roots actions of the residents can create third places.

\section{STRUCTURE OF THE BOOK}

The book explores the virtual and geographical understanding of place and community through the lens of third places. The first six chapters focus on theoretical and broad concepts of third place for example: rethinking third place and community (this chapter); feminist perspectives; life stage perspectives: older age and child friendly; and urban design and safety considerations: green planning and eyes on the street. The final five chapters focus on specific examples of third places: community museums; community gardens; cyber space; public transport and sidewalks.

In Chapter 2, 'Feminist Perspectives on Third Places' Simone Fullagar, Wendy O'Brien and Kathy Lloyd apply a feminist perspective to third place, concluding that women require third places that are both physically and socially transparent, that is, safe spaces. This chapter questions normative urban design assumptions often associated with white middle class male views. The feminist perspective was not included in Oldenburg's 
early work largely because the prevailing assumption of the time was that feminine space related to the home (first place). Fullagar et al. identify how third places facilitate or constrain women's right to the city. The focus on feminism in this chapter also highlights links between third place and transgender and non-binary identities. It also points to ways of thinking about gendered experiences relating to class, sexuality, culture, age and ability. Building upon Oldenburg's conception of third places as places where people interact, the authors discuss third places as more than human, places where people also interact with plants, animals and urban infrastructure. The chapter concludes with an acknowledgement that third places are essentially good and they call for more work to be done to create places that are inclusive for everyone and which allow all people to exercise their right to the place.

Chapter 3 builds on concerns of gender and third places to focus on the latter stages of a life. Sara Alidoust and Caryl Bosman analyse third places in terms of the contributions they can make to promoting social health for many people over the age of 65. Ageing populations are world-wide phenomena and there is general acknowledgement that urban design and planning principles, including the provision of third places, need to recognise and support active and healthy ageing agendas. Accessibility of amenities is critical in achieving these agendas. The chapter concludes by arguing for the planning of transport and third place interventions in sprawling suburban landscapes, to allow older people more opportunities to be socially connected.

The other end of the lifecycle continuum is taken up in Chapter 4 by Geoff Woolcock in his chapter on child-friendly third places. Geoff investigates third places in relation to how child friendly they are, using South Bank Parklands in Brisbane, Australia as a case study. He unpacks the significance of built and natural third places in the health and well-being of children and young people. Woolcock paints a disturbing picture of childhood obesity, inactivity and social disconnectedness and argues for the importance of well designed third places that, "not only welcome children but also establish social and psychological connections that stimulate learning and ultimately, active civic participation'. The chapter provides the traits of effective child-friendly third places including opportunities for unstructured, challenging, adventurous (but safe) play.

Elizelle Juaneé Cilliers' chapter, Chapter 5, seeks to demonstrate the value and role of planning in creating and recreating public spaces which are third places; neutral places which provide opportunities for people to meet and interact and to develop a sense of being a part of a place. To do this she identifies a number of design elements to support the provision and reclaiming of third places in contemporary urban contexts. Through 
different approaches to planning (place-making, green planning and lively planning) she establishes an evidence-based framework using five international, best-practice case studies to develop third places. The chapter concludes with a global challenge 'to change life, we must first change spaces into third places'.

In keeping with the urban planning/design theme, in Chapter 6 Gordon Holden draws on Jane Jacobs' 'Eyes on the Street' to examine the role of third place in improving perceived safety. Holden focuses on the multidimensional and interconnected aspects of perceived and actual safety within the context of third places in neighbourhoods. He discusses the complexities surrounding the concept of neighbourhoods and the positive arguments for 'eyes on the street' in urban environments as means to create perceived and actual zones of safety. Holden proposes that third places contribute to 'eyes on the street' and therefore safety because these places act as nodes, attracting public participation and interaction. Through the use of four case studies on the Gold Coast, Australia he explores the presence or absence of third places within the context of recorded crime in those places. He concludes that third places may well contribute significantly to both the perception of and actual safety of a place and lower crime rates.

The remaining chapters in the book look at particular sites as third places. The concept of third place also includes places that foster hobbies and collective networks as in the theme of Chapter 7: 'Understanding Popular Music Heritage Practice Through the Lens of "Third Place". Lauren Istvandity, Sarah Baker, Jez Collins, Simone Driessen, and Catherine Strong draw from different case studies ranging from do-ityourself archiving, digital archives, walking tours, and pop music reunion tours to build a convincing augment for the value and currency of alternative third places in urban areas. Baker, in particular, points to the value of community archives and museums as third places which foster social health and can prevent an increase in social isolation among older single adults. In the same chapter Collins posits third places in the virtual online space. This new variety of third place, she argues, allows 'individuals [to] come together online, forming communities dedicated to creating, populating, sustaining and celebrating alternative popular music histories'. The final section of this chapter focuses on tours as third places. Strong's thesis is built around 'how the physical space of urban environments plays a role in how popular music is remembered'. She argues that walking tours are inherently third places. Driessen considers how 'the reunion concert tour of heritage music acts as a site where aspects of third place are enacted'. In this understanding of third place, the reunion concert venue becomes a temporary third place. 
Chapter 8, by Joanne Dolley is entitled 'Third Places and Social Capital: Case Study Community Gardens'. This chapter explores the literature on community gardens and the author's recent research which investigated community gardens against third place characteristics in a range of locations in Australia and Denmark. All of the case study community gardens exhibited most or all of the eight third place characteristics and some were particularly effective third places. The theoretical framework used for this research project is social capital and more specifically, Granovetter's 'weak ties'. The chapter gives examples of ways in which community gardens can act as third places. The findings provide insights for better design of third places and the design of community gardens, where building social capital and sense of community is a goal.

Dmitri Williams and Do Own Kim's chapter, 'Third Places in the Ether Around Us: Layers on the Real World', focuses on the third places which exist beyond the 'physical realm' to non-physical spaces made possible through technology. They approach the topic through theories utilised in the study of computer-mediated communication, in particular the concept of 'layering' of multiple online and offline environments. Williams and Kim outline the strengths and weaknesses of virtual places over real-world places. They identify aspects of virtual space which enhance third place interactions by cutting through barriers of socio-economic status and physical attributes. However, the authors caution on the use of filter bubbles, which feed us interactions with like-minded people, isolating our social connections somewhat like a gated community - possibly Oldenburg's 'worst nightmare'. Williams and Kim also draw attention to new technology blurring the edges between first, second and third places, for example, as social media interrupts work, work emails edge into home life, and third place virtual games take place at home. The chapter concludes that as we move into an 'ever-more technologically mediated future', technology has potential to provide third places to anyone anywhere, but just as physical architecture influences human behaviour, it is important to consider the design of the social 'architecture' of online spaces.

Chapter 10 focuses on public transport as a third place. Daniel O'Hare 'considers whether the public transport commute, historically a linear experience between the workplace and home, can be a third place rather than a soulless shuttle to be bracketed with "work" as the opposite to "home". O'Hare examines the changing nature and form of work and he links this to the design of cities and the experience of commuters' journeys. He posits that many young adults today (2018) are choosing not to drive and consequently the use of public transport, active modes of travel and third places are flourishing. Public transport is continually shaping and 
reshaping the level of passenger interaction, with in-vehicle design and waiting areas (station/stop) designs either facilitating or limiting certain types of interactions. The use of mobile technology means many public transport users can connect to virtual communities and so transform the travel journey into a third place. The chapter ends with a call for a greater recognition of public transport as a third place to be 'enjoyed rather than endured' and that well-designed and managed public transport contributes to people-centred cities.

The final chapter, Chapter 11, by Leila Mahmoudi Farahani and David Beynon, focuses on streets as sites of third place activity. By analysing the unobtrusive video footage of interactions which occur along several commercial streets in the City of Greater Geelong, Victoria, it was determined that sidewalk cafés and restaurants, shops and interaction zones such street crossings act, in varying degrees, as third places. Their methodology of video analysis of the use of space and their depiction of findings through diagrams provides a unique level of detail of third place interactions. Using their data and referring theoretically to Lefebvre's ideas on meanings in space, they are able to comment on what makes a vital, active streetscape and propose design features which can enhance the design of third places.

\section{CONCLUDING THOUGHTS}

Third places are neutral, open places which act as levellers to bring together local residents of different ethnicities, ages, genders, socio-economic status, education levels and interests. Third places are sites of diversity where everyone is welcome, free to come and go and feel comfortable. Third places can play an important role in improving social interactions in neighbourhoods. Ray Oldenburg, the creator of the concept, listed many examples of third places, such as parks, cafés and piazzas, where people could meet informally. This chapter provides the historical and current urban planning context in which third places reside. This book is a timely exploration of the role of third place in building relations of community in a modern highly urbanised mobile society.

\section{REFERENCES}

Audirac, I. (1999) 'Stated preference for pedestrian proximity: An assessment of new urbanist sense of community', Journal of Planning Education and Research, 19(1): 53-66. 
Audirac, I. and Shermyen, A.H. (1994) 'An evaluation of neotraditional design's social prescription: Postmodern placebo or remedy for suburban malaise?' Journal of Planning Education and Research, 13(3): 161-173.

Barton, H. (2000) 'Conflicting perceptions of neighbourhood'. In Barton, H. (ed.) Sustainable Communities. London: Earthscan, pp. 3-17.

Calthorpe, P. (1994) 'The region'. In Katz, P. (ed.) The New Urbanism: Toward an Architecture of Community. New York: McGraw-Hill, pp. xi-xvi.

Congress for the New Urbanism (1998) 'Charter of the new urbanism'. Available: www.cnu.org (accessed 3 December 2018).

Davison, G. (1993) 'The past and the future of the Australian suburb'. In Coles, R.C. (ed.) Urban Research Program. Canberra: Research School of Social Sciences, Australian National University, pp. 1-26.

Dennis, N. (1968) 'The popularity of the neighbourhood community idea'. In Pahl, R.E. (ed.) Readings in Urban Sociology. London: Pergamon, pp. 74-92.

Duany, A. and Plater-Zyberk, E. (1994) 'The neighborhood, the district and the corridor'. In Katz, P. (ed.) The New Urbanism: Toward an Architecture of Community. New York: McGraw-Hill, pp. xvii-xx.

Firth, C., Maye, D. and Pearson, D. (2011) 'Developing "community" in community gardens', Local Environment: The International Journal of Justice and Sustainability, 16(6): 555-568.

Freestone, R. (1989) Model Communities: The Garden City Movement in Australia. Melbourne: Thomas Nelson Australia.

Freie, J.F. (1998) Counterfeit Community: The Exploitation of Our Longings for Connectedness. Maryland: Rowman \& Littlefield.

Fulton, W. (1996) 'The new urbanism challenges conventional planning', Land Lines, September 8(5).

Galdini, R. (2016) 'Placemaking as an approach for innovative urban renewal practices: Community gardens in Berlin', International Review of Sociology, 2016: 1-21.

Gilchrist, A. (2000) 'Designing for living: The challenge of sustainable communities'. In Barton, H. (ed.) Sustainable Communities. London, Earthscan, pp. 147-159.

Hall, P. and Ward, C. (1998) Sociable Cities: The Legacy of Ebenezer Howard. London: John Wiley \& Sons.

Heraud, B.J. (1968) 'Social class and the new towns', Urban Studies, 5: 33-58.

Hollis, L. (2013) Cities Are Good for You: The Genius of the Metropolis. London: Bloomsbury Publishing.

Howard, E. (1898) To-morrow: A Peaceful Path to Real Reform. London: Swan Sonnenschein \& Co.

Jacobs, J. (1972) The Death and Life of Great American Cities. London: Penguin.

Jacobs, M. (1996) The Politics of the Real World. Meeting the New Century. London: Earthscan Publications.

Jones, H., Neal, S., Mohan, G., Connell, K., Cochrane, A. and Bennett, K. (2015) 'Urban multiculture and everyday encounters in semi-public, franchised café spaces'. The Sociological Review, 63(3): 644-661.

Katz, P. (1994) 'Preface'. In Katz, P. (ed.) The New Urbanism: Toward an Architecture of Community. New York: McGraw-Hill, pp. ix-x.

Landecker, H. (1996) 'Is new urbanism good for America?' Architecture AIA Journal, 85(4): 68-77.

Mele, C., Ng, M. and Chim, M. (2015) 'Urban markets as a "corrective” to advanced 
urbanism: The social space of wet markets in contemporary Singapore'. Urban Studies, 52(1): 103-120.

Mumford, L. (1991) The City In History: Its Origins, its Transformations and its Prospects. London: Penguin Books.

Oldenburg, R. (1989) The Great Good Place: Cafes, Coffee Shops, Community Centers, Beauty Parlors, General Stores, Bars, Hangouts, and How They Get You Through the Day. New York: Paragon House.

Oldenburg, R. (1997) 'Our vanishing third places'. Planning Commissioners Journal, 25: 6-11.

Oldenburg, R. (1999) The Great Good Place: Cafes, Coffee Shops, Bookstores, Bars, Hair Salons, and Other Hangouts at the Heart of a Community. New York: Marlow \& Company.

Oldenburg, R. (2001) Celebrating the Third Place: Inspiring Stories about the 'Great Good Places' at the Heart of Our Communities. Boston: Da Capo Press.

Osborne, T. and Rose, N. (1999) 'Governing cities: Notes on the spatialisation of virtue', Environment and Planning D: Society and Space, 17(6): 737-760.

Peel, M. (1992) 'Planning the good city in Australia: Elizabeth as a new town'. In Coles, R.C. (ed.) Urban Research Program, Working Paper No. 30, pp. 1-60. Canberra: Research School of Social Sciences, Australian National University.

Perry, C. (1929) 'The Neighborhood Unit', Monograph One. Vol. 7, Regional Survey of New York and its Environs, Neighborhood and Community Planning. New York: New York Regional Plan, 1929.

Putnam, D. (2000) Bowling Alone. New York: Simon \& Schuster.

Sandercock, Leonie (1998) Towards Cosmopolis. London: John Wiley \& Sons.

Scully, V. (1994) 'The architecture of community'. In Katz, P. (ed.) The New Urbanism: Toward an Architecture of Community. New York: McGraw-Hill, pp. 221-230.

Steuteville, R. (2000) 'The new urbanism: An alternative to modern automobileorientated planning development', New Urban News, 28 June 2000. Available: www.newurbannews.com (accessed 20 December 2018).

Taylor, N. (2000) 'Eco-villages: Dreams and reality'. In Barton, H. (ed.) Sustainable Communities. London: Earthscan, pp. 19-28.

Thompson, S. and Maggin, P. (2012) Planning Australia: An Overview of Urban and Regional Planning. Cambridge: Cambridge University Press.

Unwin, R. (1901) 'Building and natural beauty'. In The Art of Building A Home. London: Longmans Green, p.93. Quoted in Creese, Walter (1986) The Search For Environment: The Garden City: Before and After. New Haven: Yale University Press.

Unwin, R. (1994) [1909]) Town Planning In Practice. New York: Princeton Architectural Press.

Vincent, C., Neal, S. and Iqbal, H. (2016) 'Encounters with diversity: Children's friendships and parental responses'. Urban Studies, 54(8): 1974-1989. 